ON SOME NEW OR LITTLE KNOWN DECAPOU CRUSTACEA, FROM RECENT FISH COMMISGION DREDGINGS OFE THE EAST COAST DF THE UNITED STATES.

\title{
By SIDNEY I. SIITH.
}

\section{Anamathia* Agassizii.}

Amathia Agassizii Smith, Bull. Mus. Comp. Zool., x, p.1, pl. 2, figs. 2,3,1882; Proe. Nat. Mus., vi, p. 3, 1883 ; Report U. S. Fish Com., x, for 1882, p. 346, 1884.

This species will probably prove to be synonymous with $A$. crassa A. Milne-Edwards, the description of which I had not seen when my species was published.

A male taken this season is almost as large as the large female taken last year. Soon after preservation in alcohol the red color upon the peræopods was very bright, and there was considerable red on the carapax also.

The name Amathia given to this genus by Roux in 1828 had been used in 1812 by Lamouroux for a genus of Bryozoa. Roux's genus in. cludes the following species:

Anamathia Rissoana (Roux). Mediterranean.

Anamathia hystrix (Stimp.). Straits of Florida.

Anamathia Tanneri (Smith). Off Delaware Bay and Martha's Vineyard.

Anamathia crassa (A. M.-Edw.). Straits of Florida.

Anamathia Agassizii (Smith). Off Carolinas and Martha's Vineyard. Anamathia modesta (Stimp.). Straits of Florida.

\section{Munidopsis Whiteaves.}

A careful examination of the structural characters of the type species of this genus with A. Milne-Edwards's Galacantha rostrata, my G. Bairdii, and the two species here described, induces me to refer them all to a single genus. The oral appendages are almost exactly alike in all the species, except unessential differences in the armament of the second gnathopods. The number and arrangement of the branchiæ are the same in all and like that in the typical species of Munida, though the number of epipods varies. In Munidopsis curvirostra and Bairdii there are only two epipods on each side as in the typical species of Munida, one at the base of the maxilliped and the other at the base of the second gnathopod; in Munidopsis crassa and similis there is an additional pair at the base of the first peræopod; while in Munidopsis rostrata there are additional ones at the bases of each of the first three pairs of peræopods. The eyes in Munidopsis Bairdii, crassa, and similis are much alike and considerably different from those of the other species, 
but it does not seem desirabie to consider such differences, or those in the number of epipods, as of generic value.

\section{Munidopsis crassa, sp. nov.}

This species, which is represented by a single specimen, resembles M. Bairdii in having spine-tipped eye-stalks and the dorsum of the pleon withont median teeth or spines, but is at once distinguished from it by the broad and stout non-spined rostrum, the spiny propodi of the ambulatory peræopods, and the very different armament of the carapax.

Female.-The carapax is very broad and the lateral margins nearly parallel. The front is gradually narrowed from between the bases of the peduncles of the antennæ into a very broad, stout, triangular, and nearly horizontal rostrum about hulf as long as the greatest breadth of the carapax, and over the bases of the ocular spines fully half as broad as long. The rostrum is flat or very slightly concave, and nearly smooth beneath, but the dorsal side has a strong median carina and is roughened with small tubercles; the sharp lateral edges are armed with a few minute teeth. There is a prominent acutely triangular spine on the anterior margin over the base of the antenna each side, and outside of this a conical spine directed forward from the angle of the small hepatic region, which really forms the antero-lateral angle of the carapax, though the anterior lobe of the branchial region expands laterally much beyond the hepatic region, and is armed at its anterior angle with a great dentiform spine, back of which there are several smaller spines on the lateral margin of this lobe and a single small one at the anterior angle of the posterior branchial lobe. The gastric region is prominent, and armed in front with a pair of sharp conical spines, and back and outside of these with many smaller spines and tubercles, as are also the anterior branchial lobes, and the extreme anterior portions of the branchial and cardiac regions. The cervical suture and the suture between the anterior and posterior lobes of the branchial region are marked by smooth grooves, of which the gastrocardiac portion of the cervical is the most conspicuous. The whole posterior part of the cardiac and branchial regions is armed with sharply crenulated, transverse, and broken rugæ with smooth spaces between, and a broader smooth space along the posterior margin, which is armed with a high double crest the edges of which are sharply crenulated.

The eye-stalks are short, broad, and somewhat cuboidal in form, are capable of very little motion, bear the rather small hemispherical white eye partially imbedded at the end, which projects on the dorso-mesial side in a slender spine longer than the diameter of the cornea, and are armed with a much smaller spine on the outer edge just back of the eye, and with a very small spine or tubercle similarly situated on the lower mesial angle.

The stout first segment of the peduncle of the antennula is armed distally with two long spines on the outer side, and beneath with a 
short, somewhat truncated and minutely dentate process. The second segment of the peduncle of the antenna is armed with a dentiform process below and a sharp tooth on the outer side; the third segment is armed with a single large distal spine on the outside; the fourth and fifth segments are only inconspicunusly armed. The flagellum is slightly compressed, more than twice as long as the carapax, and.sparsely clothed with slender setæ.

The infero-mesial edge of the merus of the second gnathopod is armed with three conical spines.

The chelipeds are not very much longer than the carapax, including the rostrum, and very stout; the merus is considerably shorter than the chela and armed with a few sharp spines along the dorsal edge and at the distal end, and with numerous small tubercles; the earpus is armed somewhat like the merus, but there are more and smaller spines at the distal end; the chela is about as long as the breadth of the carapax between the hepatic spines, more than a third as broad as long, considerably compressed vertically, somewhat roughened with small tubercles, especially along the inner edge, and with the stout and straight digits making more than half the whole length. The three pairs of ambulatory peræopods are very nearly alike and a little longer than the chelipeds; the meri and carpi are roughened with small tubercles, angulated, and armed with a series of spines above; the propodi are angulated, with all the angles rough and tuberculous and the dorsal spiny; the dactyli are very stout, very slightly tapered except near the curved, acute, and chitinous tip, and armed along the lower edge with a series of stout spiniform teeth which rapidly decrease in size and become obsolete proximally. The posterior peræopods are very nearly as in the allied species.

The pleon is about as broad as the carapax, only slightly narrowed posteriorly, and the dorsum is transversely rounded and devoid of longitudinal carinæ, teeth, or spines. The second and third somites each have two slightly roughened transverse ridges upon the dorsum separated by a smooth sulcus, but the dorsa of the succeeding somites are nearly smooth. The posterior margin of the sixth somite projects in a prominent median lobe, with a smaller and much less prominent lobe either side. The exposed parts of all the pleura are sparsely tuberculous and their lower edges obtuse. The second pleuron is broader than the others and its anterior edge upturned, leaving a broad depression between it and the prolongation of the transverse carina of the dorsum, which makes a median ridge.

The telson, uropods, and pleopods are very nearly as in M. Bairdii and $M$. rostrata.

The eggs in the recently preserved alcoholic specimen measure 3.4 by $3.6^{\mathrm{mm}}$ in less and greater diameter.

Measurements are given further on with those of the next species. 
Station 2224, September 8,1884 , north latitude $36^{\circ} 16^{\prime} 30^{\prime \prime}$, west longitude $68^{\circ} 21^{\prime}, 2,574$ fathoms, globigerina ooze, temperature $36.8^{\circ}$, one female (8563).

\section{Mundiopsis similis, sp. nov.}

This species, represented like the last by a single egg-bearing female, is very closely allied to $M$. crassa, and will possibly prove to be a variety of it. The single specimen is very much smaller than that of crassa, being only about three-eighths as long, but is evidently fully adult if not grown to the full size to which the species attains.

Female.-The form and proportions of the carapax are almost exactly as in the last species, but all the marginal spines are more slender and the only spines on the dorsal surface proper are a single pair on the anterior part of the gastric region; the rest of the anterior part of the carapax being only slightly roughened with minute transverse broken rugæ, while the posterior portions are armed very nearly as in crassa, though the carina of the posterior margin is proportionally wider and not distinctly double nor sharply crenulated.

The eyes, antennulæ, and antennæ are almost exactly as in the last species, and so are the oral appendages, except the merus of the second gnathopod, which is armed with a few scarcely spiniform tubercles in place of conical spines.

The right cheliped is considerably smaller than the left, and is appar. ently a reproduced appendage. The left is considerably more slender and much longer than in crassa, being fully once and two-thirds as long as the carapax, including the rostrum; the merus is armed along all the angles, except the outer or posterior, as well as at the distal end, with long spines; the carpus is armed dorsally with three spines at the distal end, and with one or two on the inner edge; the chela is much longer than the greatest breadth of the carapax, a third as broad as long, armed along the inner edge with two or three spines, and has the digits about half the whole length. The ambulatory peræopods are nearly alike and a little longer than in crassa; the meri and carpi are armed nearly as in that species, but the propodi each have only a single spine on the dorsal edge.

The whole dorsal surface of the pleon is nearly smooth, though there is a shallow transverse sulcus on second and third somites. The middle of the posterior margin of the sixth somite is truncated and less prominent than the small lobe on either side.

The eggs are apparently considerably smaller than in crassa, measuring 2.7 by $2.9^{\mathrm{mm}}$ in the recently preserved alcoholic specimen.

Station 2192, August 5, 1884, north latitude $39^{\circ} 46^{\prime} 30^{\prime \prime}$, west longitude $70^{\circ} 14^{\prime} 45^{\prime \prime}, 1,060$ fathoms, globigerina ooze, temperature, $38.6^{\circ}$, one female (8255). 
Vol. VIl, Vo. ஓ2. Washington, D.C. Шaน. E, 1885.

Measurements in millimeters.

\begin{tabular}{|c|c|c|}
\hline & M. crassa. & M. similis. \\
\hline $\begin{array}{l}\text { Catalogue number } \ldots \ldots \ldots \ldots \ldots \ldots \ldots \ldots \ldots \ldots \\
\text { Station }\end{array}$ & $\begin{array}{l}8563 \\
2224\end{array}$ & $\begin{array}{l}8255 \\
2192\end{array}$ \\
\hline $\begin{array}{l}\text { Sex } \\
\text { Length from tip of rostrum to tip of telson } \\
\text { Length of carapax, including rostrum } \\
\text { Length of rostrum } \\
\text { Greatest breadth of carapax, including spines } \\
\text { Breadth at bases of antero-lateral spines } \\
\text { Brearlth at branchial regions } \\
\text { Length of eyestalk, including spine }\end{array}$ & $\begin{array}{l}\text { P. } \\
125 \\
65 \\
19.2 \\
39.2 \\
29.4 \\
38.0 \\
7.5 \\
3.0 \\
2.7 \\
73 . \\
29.3 \\
10.9 \\
16.8 \\
74.0 \\
29.5 \\
11.0 \\
16.8 \\
85 \\
22.0 \\
15.4 \\
48 \\
16.0 \\
23.5 \\
13.0 \\
14.5 \\
14.5 \\
12.7\end{array}$ & \begin{tabular}{r}
\multicolumn{1}{c}{} \\
45 \\
24.2 \\
7.5 \\
13.7 \\
10.5 \\
13.3 \\
2.3 \\
1.5 \\
1.2 \\
37 \\
13.5 \\
3.2 \\
7.1 \\
41 \\
15.0 \\
5.0 \\
7.6 \\
40 \\
5.9 \\
11.3 \\
22 \\
6.0 \\
7.4 \\
5.0 \\
4.0 \\
5.2 \\
4.0
\end{tabular} \\
\hline
\end{tabular}

\section{Bythocaris gracilis, sp. nov.}

This species is closely allied to B. Payeri G. O. Sars, and is possibly only a variety of it, though the specimens seen differ conspicuously from specimens of B. Payeri, from the Faroe Channel, received from the Rev. Dr. Norman, in the size of the eyes and the form of the antennal scales.

Female.-The carapax is about two-thirds as broad as its length along the dorsum, and the front about a sixth as broad as the length and very nearly as in $B$. Payeri, but the lateral teeth are a little more prominent than in that species. The short median carina on the gastric region terminates abruptly in a small tooth anteriorly, not present in any of the specimens of B. Payeri. The eye-stalk and eye are about a fourth as long as the dorsum of the carapax, and the diameter of the black eye about three-fifths of the length of the stalk and eye. In the specimens of $B$. Payeri the eyes are considerably smaller, about a fifth as long as the carapax, and the diameter about balf the length of the eje and stalk. The first segment of the peduncle of the antenuula is armed with a very slender and acute lateral spine which reaches nearly as far forward as the segment itself. The antennal scale is fully as long as the dorsum of the carapax and less than a third as broad as long, while in B. Payeri it is rather shorter and considerably broader. The peræopods and pleon are very nearly as in $B$. Payeri.

Proc. Nat. Mus. $81-32$ 
The eggs in the alcoholic specimens are about 1.8 by $1.4^{\mathrm{mm}}$ in longer and shorter diameter.

In the following table similar measurements of this species and a specimen of B. Payeri are given for comparison.

Measurements in millimeters and hundredths of length of carapax.

\begin{tabular}{|c|c|c|}
\hline , & B. gracilis. & B. Payeri. \\
\hline Station ............... & 2116 & \\
\hline Sex ............. & q & q \\
\hline 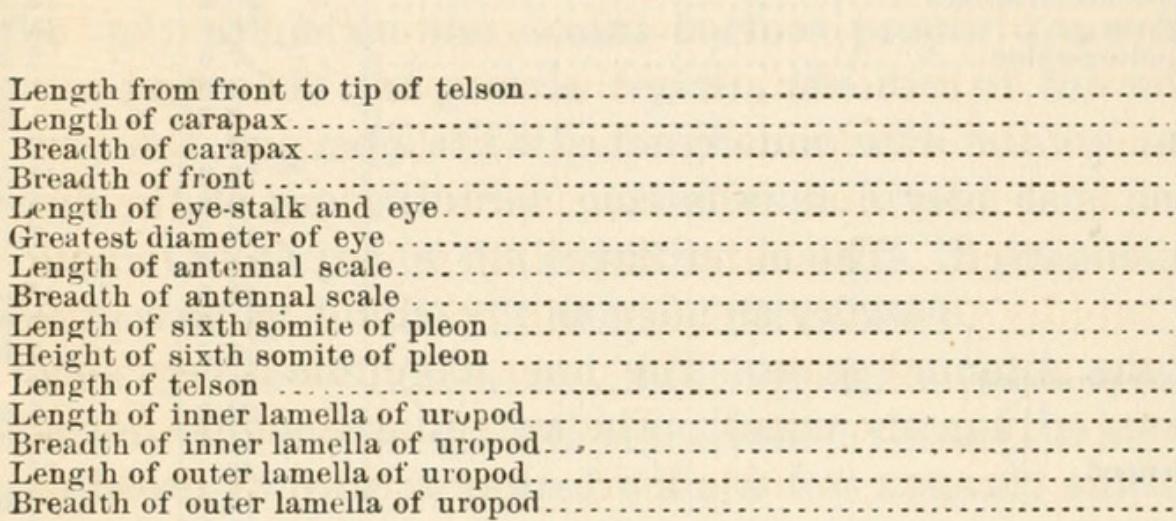 & \begin{tabular}{rr}
\multicolumn{3}{c}{ Per } \\
Mm. & cent. \\
$39.0=$ & 464 \\
8.4 & 100 \\
5.5 & 65 \\
1.4 & 17 \\
2.0 & 24 \\
1.3 & 15 \\
8.5 & 101 \\
2.8 & 35 \\
6.1 & 73 \\
2.3 & 27 \\
7.5 & 89 \\
5.6 & 67 \\
1.8 & 21 \\
7.0 & 83 \\
2.4 & 29
\end{tabular} & \begin{tabular}{rr}
\multicolumn{3}{r}{ Per } \\
Mm. cent \\
$50.0=\mathbf{4 7 6}$ \\
10.5 & 100 \\
6.7 & 64 \\
1.6 & 15 \\
2.0 & 19 \\
1.0 & 10 \\
$\mathbf{9 . 6}$ & 92 \\
$\mathbf{4 . 3}$ & 41 \\
8.0 & 76 \\
3.6 & 34 \\
9.0 & 86 \\
7.3 & 70 \\
2.4 & 23 \\
8.8 & 84 \\
3.5 & 33
\end{tabular} \\
\hline
\end{tabular}

Specimens examined.

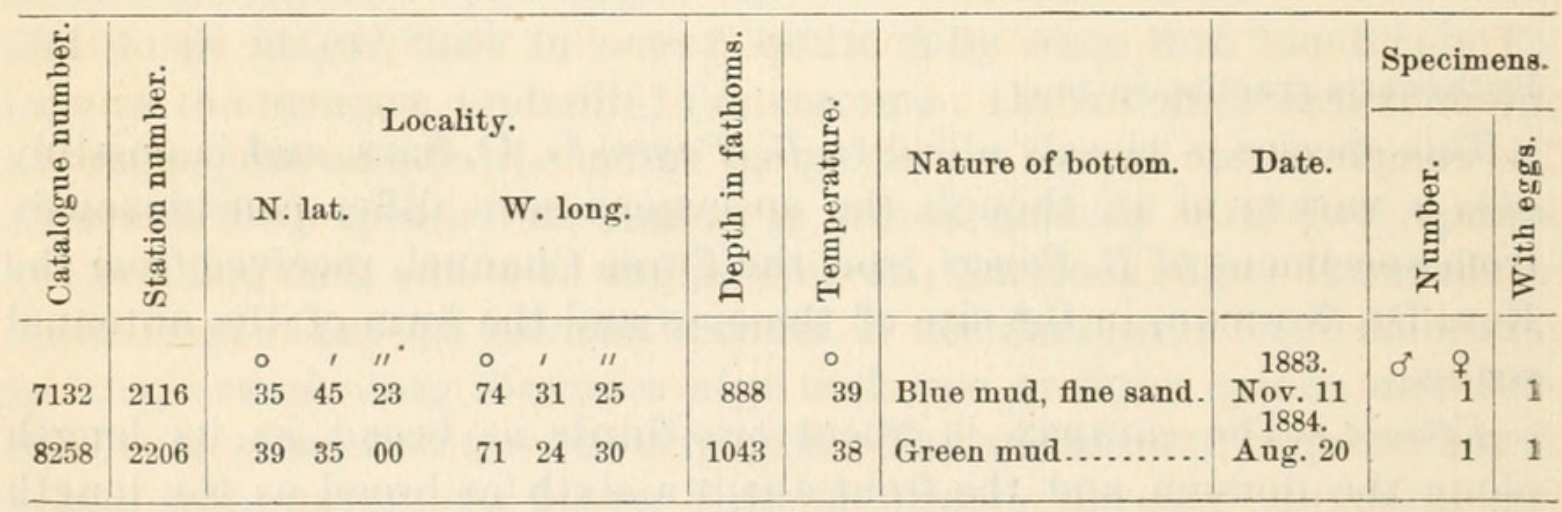

Bythocaris Payeri and the following species, B. nana, differ remarkably from Hippolyte and the allied genera in the reduced number of the branchiæ and epipods. There are no epipods proper at the bases of any of the gnathopods or peræopods, and no podobranchiæ nor arthrobran. chiæ on any of the somites, as the following branchial formula shows:

\begin{tabular}{|c|c|c|c|c|c|c|c|c|c|}
\hline & \multicolumn{8}{|c|}{ Somites. } & \multirow[b]{2}{*}{ Total. } \\
\hline & VII. & VIII. & IX. & $\mathrm{X}$. & XI. & XII. & XIII. & XIV. & \\
\hline 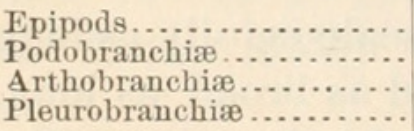 & $\begin{array}{l}1 \\
0 \\
0 \\
0\end{array}$ & $\begin{array}{l}0 \\
0 \\
0 \\
0\end{array}$ & $\begin{array}{l}0 \\
0 \\
0 \\
0\end{array}$ & $\begin{array}{l}0 \\
0 \\
0 \\
1\end{array}$ & $\begin{array}{l}0 \\
0 \\
\theta \\
1\end{array}$ & $\begin{array}{l}0 \\
0 \\
0 \\
1\end{array}$ & $\begin{array}{l}0 \\
0 \\
0 \\
1\end{array}$ & $\begin{array}{l}0 \\
0 \\
0 \\
1\end{array}$ & $\begin{array}{l} \\
0 \\
0 \\
5\end{array}$ \\
\hline & & & & & & & & & $5+(1)$ \\
\hline
\end{tabular}


Bythocaris nana, sp. nov.

This is a small species, at once distinguished from B. Payeri and $B$. gracilis by the very much broader and differently shaped front, and the much longer eye-stalks.

The carapax is about three-fourths as broad as its length along the dorsum, and the breadth of the front fully a third of the length. The supraorbital teeth are very large, and project as far forward as the very small rostral tooth. The median carina of the gastric region is low and incouspicuous.

The eyes are well developed, placed obliquely upon the stalks, and black. The length of the eye and stalk is about equal to the breadth of the front, and the diameter of the eye considerably greater than that of the stalk, equalling about a fifth the length of the carapax. The first segment of the peduncle of the antennula reaches a little beyond the eye, and its lateral spine is slender and falls considerably short of the distal end of the segment itself. The outer flagellum is very stout in both sexes, and tapers rapidly to a very slender tip, reaching to, or a little beyond, the tip of the antennal scale. The inner flagellum is very slender, and slightly longer than the outer. The antennal scale is shorter than the dorsum of the carapax, a little more than a third as broad as long, and has the tip more elongated than in the last species. The fla gellum of the antenna is very slender, subcylindrical, and much longer than the body of the animal.

The endopod of the second gnathopod reaches nearly to the tip of the antennal scale; the distal and proximal of the three segments of which it is composed are approximately equal in length; the middle segment is about two-fifths as long as the proximal, and the exopod searcely reaches to the middle of the proximal segment of the endopod and is very slender. The first peræopods reach to near the tips of the peduncles of the antennæ; the carpus and chela are together as long as the rest of the endopod; the chela is about once and two-thirds as long as the carpus, slightly stouter, about a fourth as broad as long, and the digits slender and a little less than half as long as the whole length of the chela. The second peræopods are very slender and reach considerably beyond the antennal scales; the ischium and merus are subequal in length; the carpus is a little less than twice as long as the merus, and composed of eight segments ; the chela is nearly cylindrical and about once and two-thirds as long as the distal segment of the carpus and no stouter. The third, fourth, and fifth peræopods are nearly alike, and about as long as the second; the meri and propodi are subequal in length, and the meri are armed with three to seven spines along the distal part of the lower edge; the lower edges of the propodi are clothed with a few plumose hairs, and armed with several very slender spines; the dactyli are approximately a fourth as long as the propodi, slightly curved, regularly tapered to an acute tip, and armed along the lower edge with a regular series of spinules. 
The pleon is somewhat geniculated and slightly compressed dorsally at the third somite, but none of the somites are carinated. The telson is a little shorter than the sixth somite, evenly rounded above, and regularly tapered to a narrow truncated tip armed with six slender spines, of which the sublateral pair are much larger than the lateral and median.

The eggs, in the alcoholie specimens, are approximately 1.0 by $0.8^{\mathrm{mm}}$ in longer and shorter diameter.

Many of the specimens, after long preservation in alcohol, show dark bands of pigment spots across the antennal scales, uropodal lamellæ, and somites of the pleon.

This is the species to which I have referred as Bythocaris, sp. indet., in Proc. National Mus., iii, p. 437, 1881, and Bull. Mus. Comp. Zool., x, p. 55,1882 .

Measurements in millimeters and hundredths of length of carapax.

\begin{tabular}{|c|c|c|}
\hline 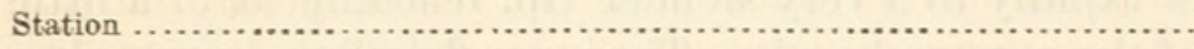 & 878. & 878. \\
\hline Sex .... & $\sigma^{8}$ & \\
\hline 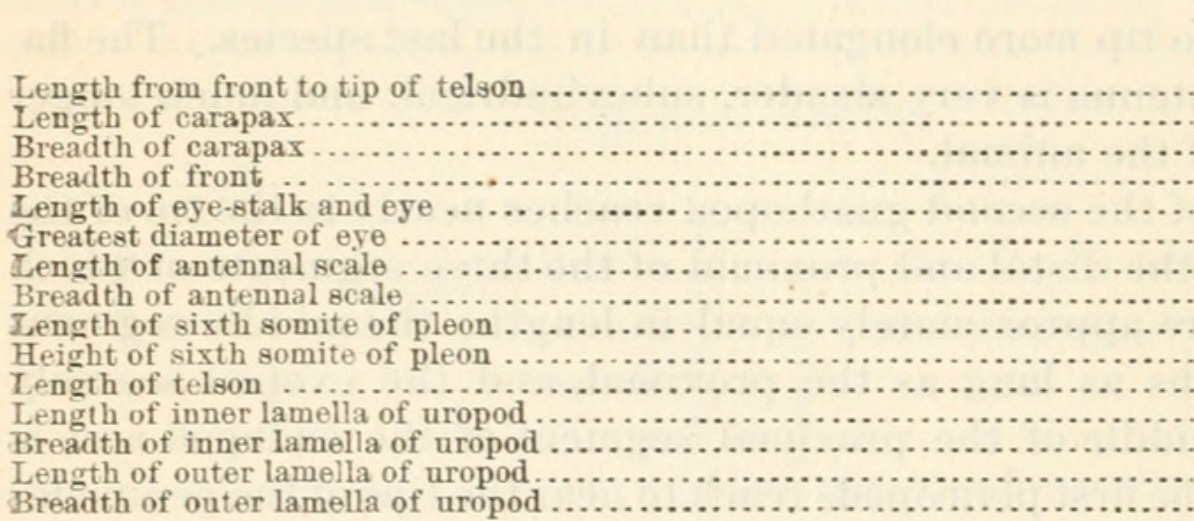 & $\begin{array}{rr}\text { Per } \\
\text { Mm. cent. } \\
25.5=455 \\
5.6 & 100 \\
4.3 & 77 \\
2.0 & 36 \\
2.0 & 36 \\
1.1 & 20 \\
5.0 & 89 \\
1.8 & 32 \\
4.1 & 73 \\
1.7 & 30 \\
4.9 & 87 \\
3.8 & 68 \\
1.1 & 20 \\
4.2 & 75 \\
1.3 & 23\end{array}$ & $\begin{array}{rr} & \text { Per } \\
\text { Mm. } & \text { cent. } \\
25.0= & 455 \\
5.5 & 100 \\
4.2 & 76 \\
1.9 & 35 \\
1.9 & 35 \\
1.1 & 20 \\
4.6 & 84 \\
1.7 & 31 \\
4.0 & 73 \\
1.8 & 33 \\
5.0 & 91 \\
3.8 & 69 \\
1.1 & 20 \\
4.3 & 78 \\
1.4 & 26\end{array}$ \\
\hline
\end{tabular}

Specimens examined.

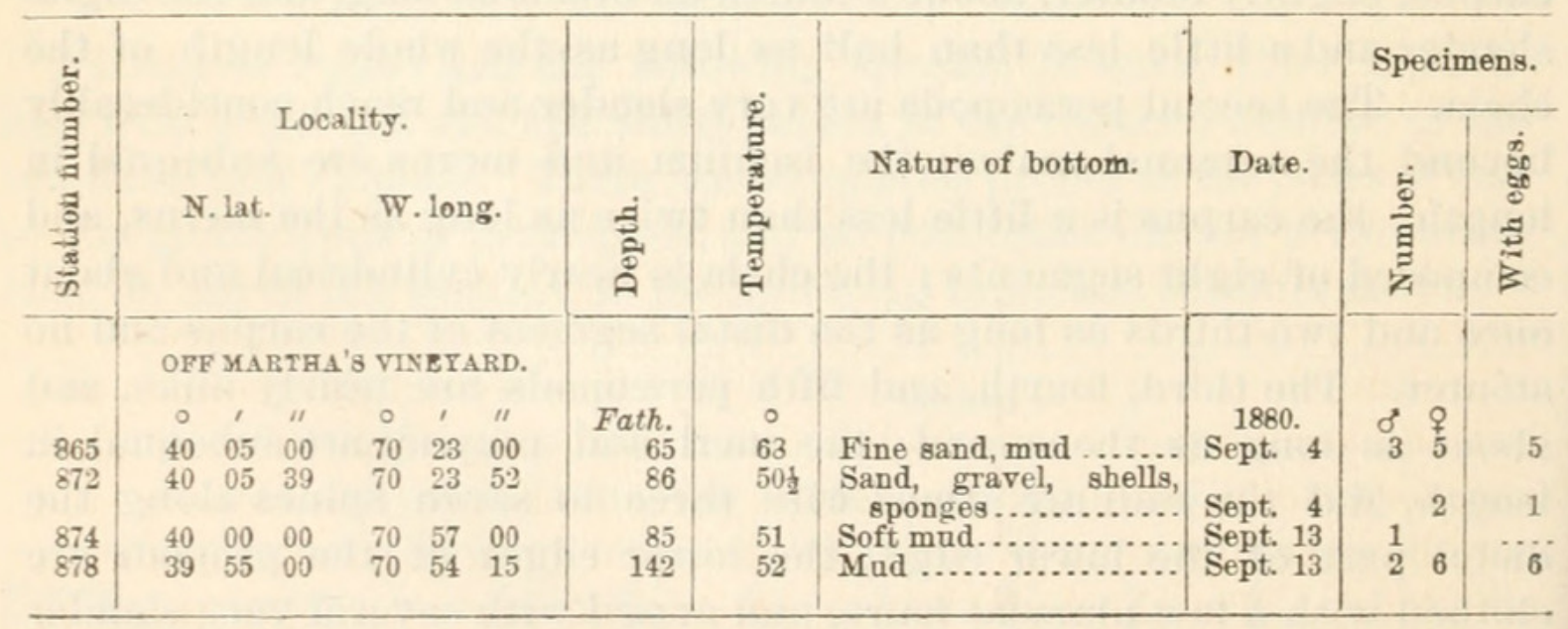


Hymenodora glacialis G. O. Sars.

Pasiphaè glacialis Buchholz, Zweite deutsche Nordpolfahrt, ii, p. 279, pl. 1, fig. 1, 1874.

Hymenodora glacialis G. O. Sars, Archiv Mathem. Naturvid., Kristiana, ii, p. 341, 1877. Norman, Proc. Royal Soc. Edinburgh, 1881-82, p. 684, 1882.

A few specimens from the Albatross dredgings of 1883 were doubtfully referred to this species, but Buchholz's erroneous figures and Sars's short diagnosis left the identification so uncertain that I did not mention them in the published report. Authentically labeled specimens from the Faroe Channel, recently received from the Rev. A. M. Norman, to whose kindness in sending them I am greatly indebted, confirm the identification, however, and enable me to positively refer the genus to the Acanthephyrinæ and to compare the single species with the closely allied forms, and particularly with my genus Meningodora.

The eye-stalks and eyes arè very similar to those of Meningodora mollis, but the eyes are apparently a little smaller and are reddish instead of black in recently preserved alcoholic specimens.

The mandibles are similar to those of Meningodora mollis, but still more like those of Acanthephyra Agassizii, the mesial edges being armed very nearly as in that species. The distal segment of the protognath of the first maxilla is very much broader than in Meningodora mollis or any of the species of Acanthephyra which I have examined, the mesial edge being fully as long as that of the proximal segment, which, however, is considerab!y narrower mesially than in Meningodora mollis; the endo. gnath is like that of the Meningodora. The two divisions of the distal segment of the protognath of the second maxilla are nearly equal and much broader and shorter than in Meningodora mollis, and do not project mesially beyond the proximal segment, as they do in the species of Acanthephyra, Meningodora, Notostomus, and Ephyrina; otherwise the second maxillæ do not differ from those of Meningodora. The maxullipeds differ essentially from those in the allied genera in having the endopod composed of two segments only, a very short proximal segment and a long unsegmented distal one.

The first gnathopods bear no podobranchiæ, and the distal part of the endognath differs from that of Meningodora mollis in having the dactylus nearly as long as broad and attached to the propodus by a much less oblique articulation. The number aud arrangement of the branchiæ and epipods on the succeeding somites are the same as in the allied forms, so that there are in all, on each side, six epipods, six arthrobranchiæ, and five pleurobranchiæ. The second gnathopods and first and second peræopods do not differ essentially from those of Men inogodora mollis, although the second peræopods are less slender and more like the first than in that species, and both pairs are somewhat more hairy. The third and fourth peræopods are more like those of Acanthephyra Agassizii than those of Meningodora mollis, being armed with small spines and setæ, and the propodi and dactyli neither grooved 
conspicuously nor earinated. The fifth peræopods are shorter and stouter than in Meningodora and rery distinctly subchelate, the stout and conspicuous, though short, dactylus elosing against a digital process of the propodus fully half its own length.

The dorsum of the pleon is neither carinated nor toothed. The pleura of the second somite are not as figured by Buchholz, but overlap those of the first and third as in the allied genera, and the pleura of the third, fourth, and fifth somites are evenly and similarly rounded posteriorly.

Specimens examined.

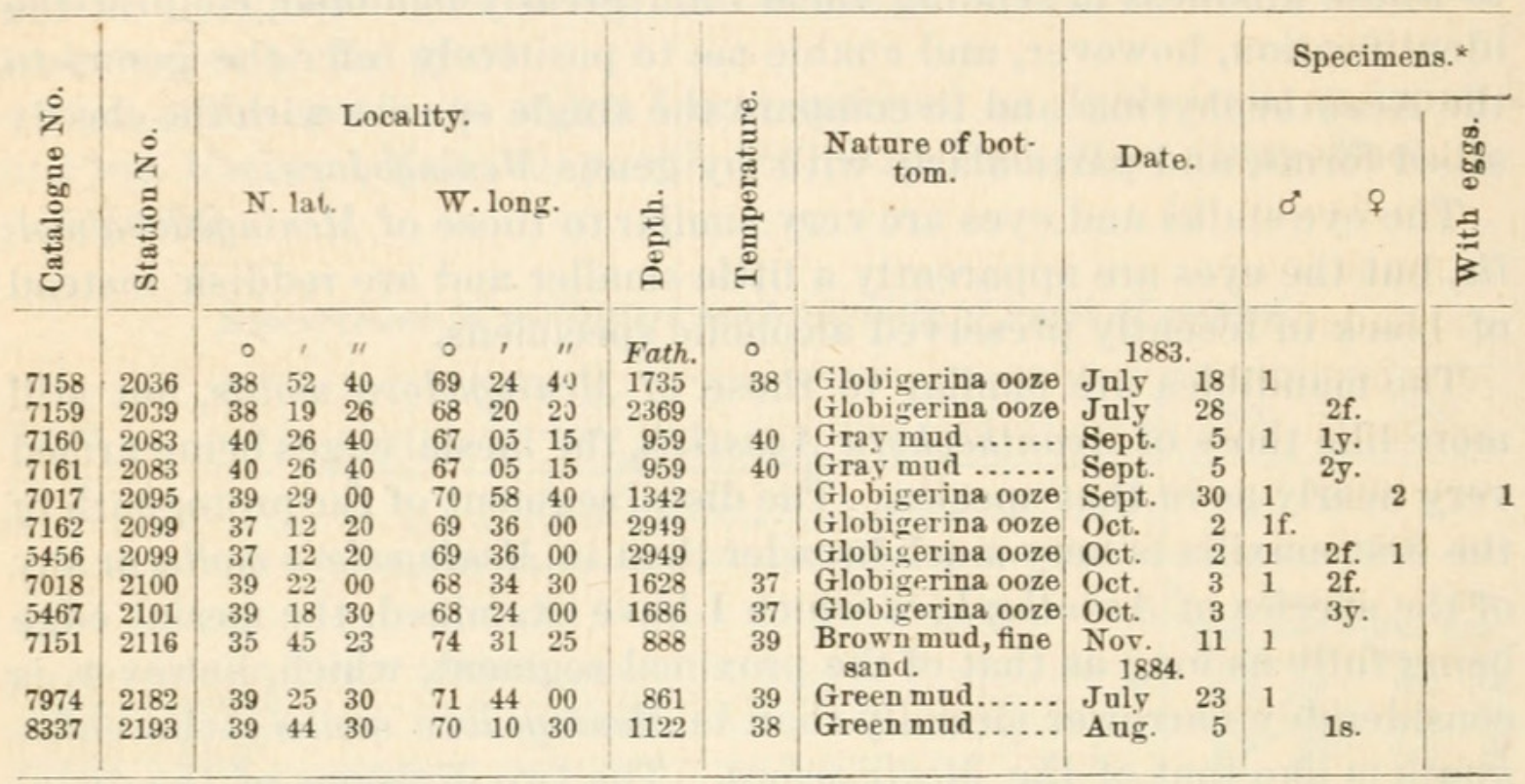

* After the number of specimens, y indicates young, s, small, and f, fragmentary.

Acanthephyra microphthalma, sp. nov.

The carapax is scarcely as broad in front as at the middle of the branchial region, and is neither compressed nor carinated dorsally, but broadly rounded, except at the high and laterally compressed base of the very slender rostrum, which is strongly upturned, wholly unarmed above except by three very obscure teeth above the orbit, and armed beneath with a series of about seven small and nearly equidistant teeth on the distal two thirds of the length, but not quite reaching the very slender and acute tip. The orbital sinus is much smaller than in A. Agassizii, the lobe beneath is much broader and somewhat truncated, and the antennal and branchiostegial spines are less prominent.

The eye-stalks are much shorter than in A. Agassizii, strongly tapered from near the base to the minute brownish eyes, which are placed obliquely upon the outer side of the tip of the stalk.

The proximal segment of the peduncle of the antennula is less deeply excavated for the reception of the eye than in A. Agassizii, and the expanded proximal portion of the outer flagellum is a little narrower, but otherwise the antennula is as in that species.

The antennal scale is about two thirds as long as the carapax exclud. ing the rostrum, near the base about a fourth as broad as long, and 
narrowed to a truncated tip about a third as broad as the base. The spine upon the second segment of the peduncle below the articulation of the scale is much shorter than in A. Agassizii.

The oral appendages differ only slightly from those of A. Agassizii. The mandibles are thicker and heavier, the opposing edges of the ventral processes a little narrower, and their teeth fewer in number, thick and obtuse, and the terminal segment of the palpus is a little narrower. The mandibles are in fact more like those of A. eximea. The fold on the ventral side near the tip of the endopod of the first maxilla is armed, in place of the two to four short spines in A. Agassizii, with a series of ten to twelve setæ, of which the proximal are stout, and somewhat spiniform, lut the distal very slender. The two lobes of the distal segment of the protognath and the endognath of the second maxilla are slightly more slender than in A. Agassizii. The anterior lobe of the scaphognath is much longer and narrower, contracted near the middle and slightly expanded at the obtuse and somewhat truncated tip, while the posterior lobe is slightly broader. The endopods and exopods of the maxillipeds are much longer and more slender than in A. Agassizii, but these appendages do not differ in other respects. The propodus and dactylus of the first gnathopod are a little more narrowed distally, and the line of articulation between them slightly less oblique than in A. Agassizii. The second gnathopods differ scarcely at all.

The peræopods are similar to those of Acanthephyra Agassizii, but are a little more slender, somewhat less hairy, and the proportions of the segments slightly different; the carpus in the second pair is nearly as long as the merus and much longer than the chela, which is considerably shorter and much more slender than in the first; and the carpi in the third, fourth, and fifth pairs are relatively shorter than in $A$. Agassizii.

The first and second somites of the pleon are rounded above, but the third and fourth are very strongly compressed dorsally and project in a very high and sharp crest, highest at the articulation between the two somites and on the third produced into a very long, slender, compressed, and spiniform tooth which is arched over nearly or quite the whole length of the fourth somite, which is itself without any earinal tooth. The fifth and sixth somites are sharply carinated dorsally, but the carina does not project in a tooth or spine on either. The pleura are of about the same form as in A. Agassizii, but are somewhat less deep.

The telson is very long and slender, only very obscurely suleated above, armed with seven or eight pairs of small dorsal aculei, and tipped with three to five slender spines between a pair of much larger lateral ones.

The uropods and pleopods are nearly as in A. Agassizii, but the ovate inner lanelliform ramus of the first pleopod of the male is a little nar. rower and the marginal stylet reaches slightly beyond the tip of the lamella itself. 
Measurements in millimeters.

\begin{tabular}{|c|c|}
\hline Sex & $\sigma^{\circ}$ \\
\hline Length from tip of rostrum to tip of telson.... & 98 \\
\hline Length of carapax, including rostium ......... & \\
\hline 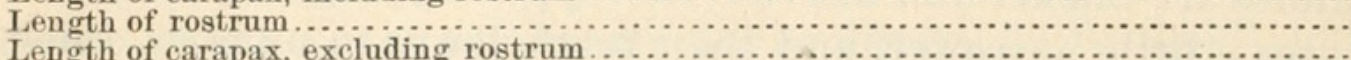 & 22.5 \\
\hline Length of earapax, excluding rostrum...... & 22.0 \\
\hline $\begin{array}{l}\text { Height of carapax } \\
\text { Breadth of carapax at branchiostegial spines } \ldots \ldots \ldots \ldots \ldots\end{array}$ & 13.5 \\
\hline 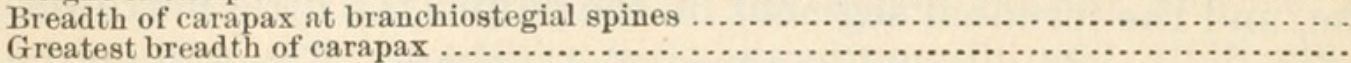 & 9.0 \\
\hline $\begin{array}{l}\text { Greatest breadth of earapax } \ldots \ldots \ldots \ldots \ldots \ldots \ldots \ldots \\
\text { Length of eye-stalk and eye } \ldots \ldots \ldots \ldots \ldots \ldots \ldots\end{array}$ & 9.8 \\
\hline $\begin{array}{l}\text { Length of eye-stalk and eye .... } \\
\text { Greatest diameter of eye........ }\end{array}$ & 2.7 \\
\hline $\begin{array}{l}\text { Greatest diameter of } \\
\text { Length of antennal sc }\end{array}$ & \\
\hline $\begin{array}{l}\text { Length of antennal sc } \\
\text { Breadth of antennal s }\end{array}$ & 14.5 \\
\hline n. & 3.6 \\
\hline $\begin{array}{l}\text { Length of second gnathopod..... } \\
\text { Length of first peræopod......... }\end{array}$ & 22.0 \\
\hline $\begin{array}{l}\text { Length of first peræopod ........... } \\
\text { Length of ehela.................. }\end{array}$ & 18. 0 \\
\hline of chela... & $\begin{array}{l}3.6 \\
0.9\end{array}$ \\
\hline f dactylus ................ & $\begin{array}{l}0.9 \\
1.2\end{array}$ \\
\hline cond peræopod...... & 21. 0 \\
\hline 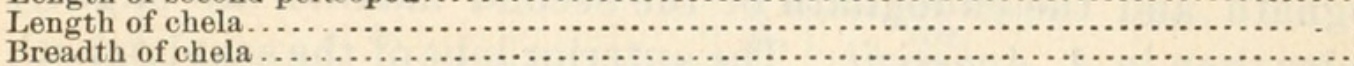 & 3.4 \\
\hline of chela & 0.7 \\
\hline 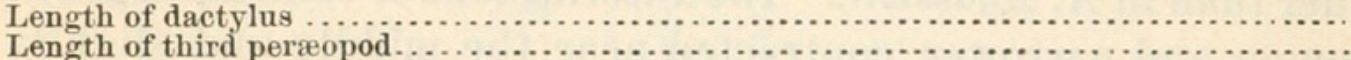 & 1. 1 \\
\hline 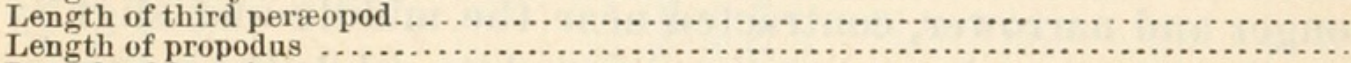 & $\begin{array}{r}25.0 \\
6.4\end{array}$ \\
\hline 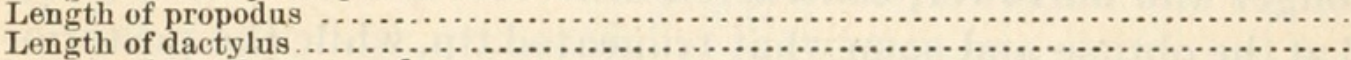 & $\begin{array}{l}\text { 6. } 4 \\
\text { 1. } 7\end{array}$ \\
\hline peræopod & 24. 0 \\
\hline us & 6. 1 \\
\hline encos & 1.6 \\
\hline (n) & 22.0 \\
\hline 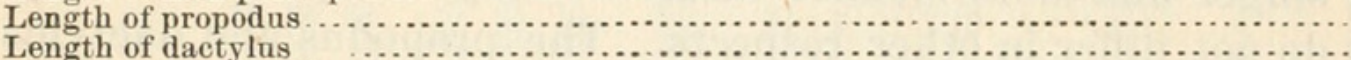 & 7. \\
\hline pleon $\ldots \ldots \ldots \ldots \ldots \ldots \ldots \ldots \ldots$ & \\
\hline 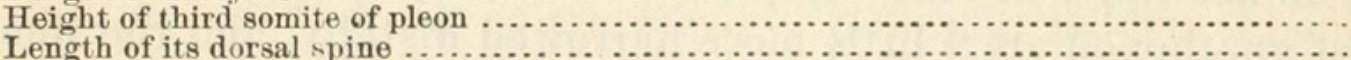 & 16. 0 \\
\hline n & 9.5 \\
\hline f sixth somite of pleon & 10.5 \\
\hline 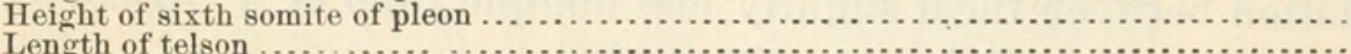 & 6. 0 \\
\hline 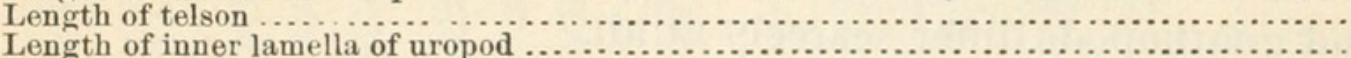 & 17. 0 \\
\hline 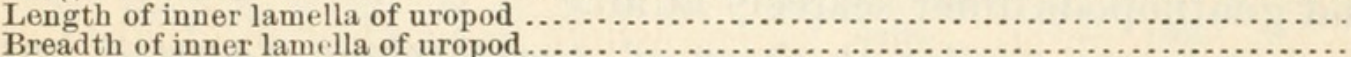 & 12.1 \\
\hline f uropod $f_{n}$ & $\begin{array}{r}2.7 \\
13.4\end{array}$ \\
\hline 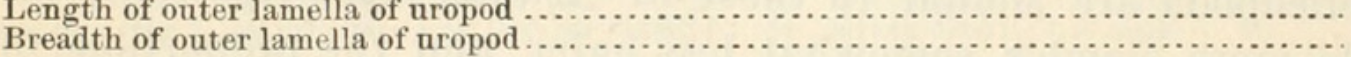 & $\begin{array}{r}10.4 \\
3.3\end{array}$ \\
\hline
\end{tabular}

Station 2224, September 8, 1884, north latitude $36^{\circ} 16^{\prime} 30^{\prime \prime}$, west longitude $68^{\circ} 21^{\prime}, 2,574$ fathoms, globigerina ooze, temperature $36^{\circ} .8$, two males and two females (8584).

Acanthephyra brevirostris, sp. nov.

This species is at once distinguished from the others of the genus by the very short rostrum (which, though considerably longer, strikingly recalls that of Hymenodora glacialis), and the very large, laterally compressed, and carinate tooth of the third somite of the pleon. All the specimens are in bad condition, very largely due, apparently, to the soft and membranzeeous character of the integument, which resembles that of Meningodora mollis and several other deep-water species.

The carapax proper is higher and more compressed at the base of the rostrum than in A. Agassizii and the branchiostegial spines are less prominent. The rostrum is approximately a fourth as long as the rest of the carapax, very high at base as in A. eximea, acutely triangular in a side view, terminates in a slender and slightly upturned tip, and is unarmed below but armed above, at base and back upon the carina of the carapax, with a series of five or six very small and obscure teeth.

The eye-stalks are a little shorter than in A. Agassizii and the eyes a little smaller, but broader than the stalks, some what compressed verti- 
cally, face obliquely inward and forward, and are black or brownish black. The peduncle of the antenna and its scale are nearly like those of A. microphthalma.

The oral appendages are very nearly as in A. Agassizii. The opposing edges of the ventral processes of the mandibles are a little narrower, almost exactly alike on the two sides, armed with about seven teeth each, and without the small anterior teeth seen in A. Agassizii. The first maxillæ show no differences. The divisions of the distal segment. of the protognath of the second maxilla are very slightly broader than in $A$. Agassizii, the endognath and the anterior lobe of the scaphognath are both considerably longer and the posterior lobe of the scaphognath slightly narrower. The exopod of the maxilliped does not reach beyond the endopod and the tip is broader and more truncated than in A. Agassizii. The gnathopods do not differ essentially from those of A. Agassizii.

The peræopods are very similar to those of A. Agassizii, but are all considerably longer and more slender; the first reach to the middle of the antennal scale, the fourth to considerably by its tip, and the fifth to about the same point as the first.

The pleon is smaller relatively to the cephalo-peræon than in A. Agas. sizii and the third somite very differently armed. The first and second somites are rounded above, but the third is strongly compressed dorsally into a very high and sharp carina which projects in a great laterally compressed tooth high at base, tapered to an acute point and overhanging the fourth somite and part of the fifth. The fourth, fifth, and sixth somites are compressed and armed with a sharp carina which projects posteriorly in a conspicuous tooth on the fourth, and in a similar but much smaller tooth on the fifth and sixth. The pleura are similar to those of A. Agassizii, but relatively less deep, the second is considerably broader, and the third, fourth, and fifth more produced and more evenly rounded posteriorly.

The telson is very long and slender, only very obscurely suleated above, armed with approximately five pairs of minute dorsal aculei and tipped with three slender spines between a pair of much larger lateral ones with a small subterminal spine near the base of each.

The uropods and pleopods are nearly as in A. Agassizii.

Measurements in millimeters.

\begin{tabular}{|c|c|c|}
\hline 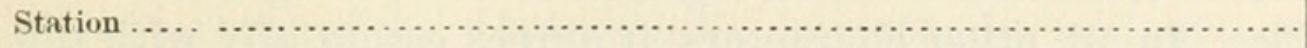 & 2105. & 2099. \\
\hline Sex ....... & $\sigma^{2}$ & q \\
\hline 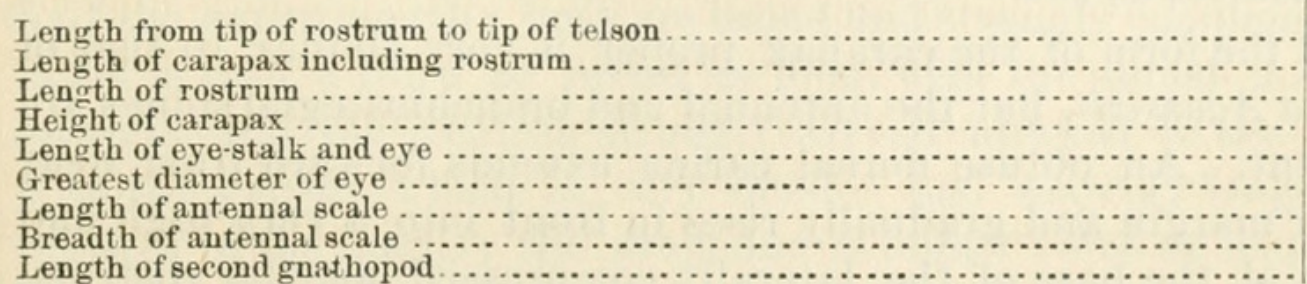 & $\begin{array}{r}65 \\
23.0 \\
5.1 \\
10.6 \\
2.8 \\
1.5 \\
10.7 \\
3.1 \\
1\end{array}$ & $\begin{array}{r}\text { 77. } \\
26.0 \\
6.9 \\
11.7 \\
3.1 \\
1.8 \\
12.1 \\
3.5 \\
21\end{array}$ \\
\hline
\end{tabular}


Measurements in millimeters-Continued.

\begin{tabular}{|c|c|c|}
\hline Station ..... & 2105. & 2099. \\
\hline Sex & $0^{\circ}$ & q \\
\hline Length of first peræopod.... & & \\
\hline Length of chela ................. & 3.9 & 4.4 \\
\hline Breadth of chela.... & 0.8 & 0.9 \\
\hline Length of dactylus......... & 1.2 & 1.3 \\
\hline Length of second peræopod. & 20 & 22 \\
\hline Length of chela ............ & 4.2 & 4.9 \\
\hline h of chela .... & 0.5 & 0.6 \\
\hline 1 of dactylus ......... & 1. 2 & 1.4 \\
\hline Length of third peræopod & & 27.0 \\
\hline Length of propodus.... & & 8.0 \\
\hline Leng & …..... & 1.9 \\
\hline peræopod & 26 & \\
\hline Lengt & 7.1 & \\
\hline Leng & 2.1 & \\
\hline æopod... & 21. & 25 \\
\hline Leng & 7.6 & \\
\hline Leng & 0.5 & \\
\hline pleon.... & 11. 0 & \\
\hline Len: & 8.4 & 9. 0 \\
\hline . $\cdots \cdots \cdots$ & 8.2 & 9.3 \\
\hline 12 & 4. 6 & 5.2 \\
\hline (n) & 14. 0 & 15. 3 \\
\hline ....ili of uron & $\begin{array}{r}14.0 \\
9.7\end{array}$ & \\
\hline & 2.1 & \\
\hline & 10.6 & 11.0 \\
\hline Breadth of outer lamella of uropod........................... & 2.8 & \\
\hline
\end{tabular}

Specimens examined.

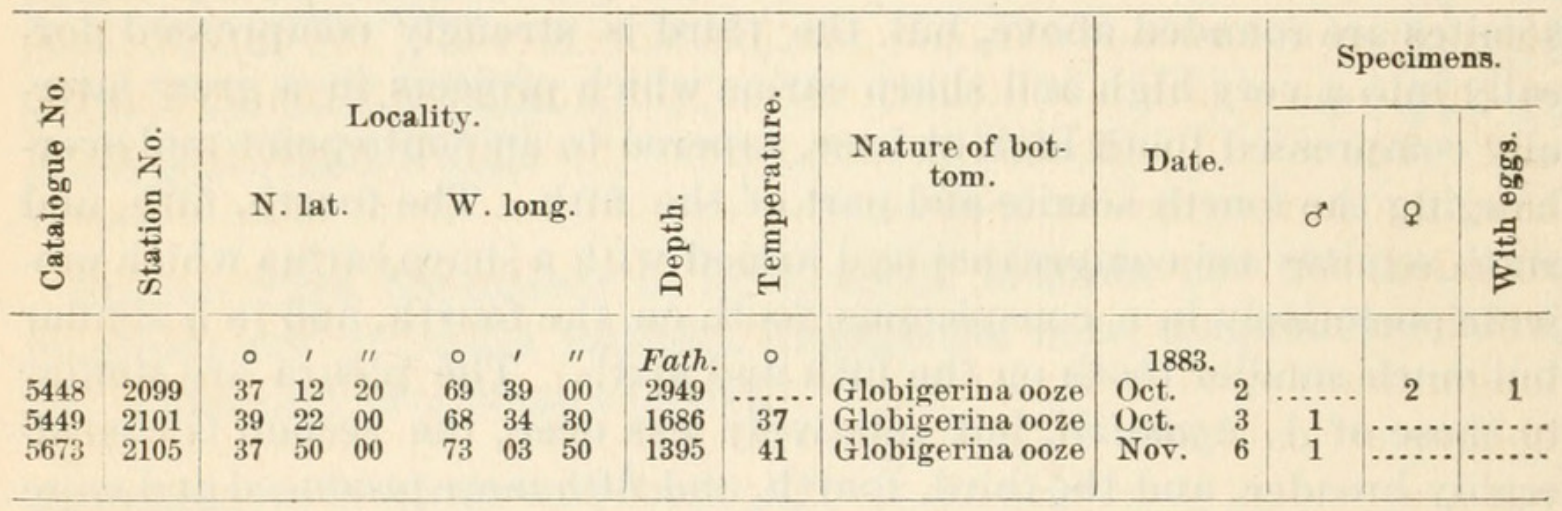

Ephyrina, gen. nov.

This genus, which is based on a single specimen, wanting the greater part of the second, third, and fourth peræopods, is readily distinguished from Acanthephyra by the ischial and meral segments of the fifth peræopods, which are compressed, very broad, and form broad lamellar opercula along the sides of the carapax. The single species is further distinguished by the unarmed rostrum, the non-carinated pleon, and the broad anterior division of the distal segment of the protognath of the second maxilla. In all other characters it agrees essentially with the species of Acanthephyra.

\section{Ephyrina Benedicti, sp. nov.}

In general the form of the carapax proper is very similar to that of Acanthephyra Agassizii, but the antennal and branchiostegial spines are less prominent. An obtuse dorsal carina extends forward from near the posterior margin and gradually rises in front into a very high and sharp carina at the base of the laterally compressed lamellar rostrum, 
which is short, not reaching beyond the peduncle of the antennula, acutely triangular in a side view, considerably upturned, and wholly unarmed.

As in Acanthephyra Agassizii, the eye-stalks are short and terminated by small hemispherical black eyes, which face slightly inward when the stalks are directed forward.

The antennulæ, too, are very nearly as in Acanthephyra Agassizii, except that the proximal portion of the outer flagellum is much less expanded, though very much stouter than the inner. The antennal scales are imperfect at the tips, but are less rapidly narrowed distally, and are apparently more nearly as in Acanthephyra microphthalma.

The mandibles are essentially as in Acanthephyra Agassizii, but are very nearly alike on the two sides, the posterior part of the mesial edge of the ventral process in each being armed with six or seven acutely triangular teeth, in front of which the margin is sharp and chitenous, but not serrated, though there is a small tooth at the anterior end of this unserrated edge in the right mandible and a sharp angle at the same point in the left. The first maxillæ are very like those of Acanthephyra Agassizii. The anterior division of the distal segment of the protognath of the second maxilla is much expanded at the mesial edge, where it projects farther forward and is more than twice as broad as the posterior division; the endognath is more slender; the anterior lobe of the scaphognath is a little narrower and more evenly rounded at the end. The maxillipeds do not differ from those of A. Agassizii, except that the antero-mesial angle of the exopod is a little more obtusely rounded, nor the first gnathopods, except the distal part of the endopod, which is more nearly as in Acanthephyra gracilis, the dactylus being longer than broad and terminally attached to the propodus by a slightly oblique articulation. The second gnathopods are imperfect at the tips, but are evidently very nearly as in Acanthephyra Agassizii, and apparently reach to about the tips of the antennal scales.

The first peræopods are about as long as the carapax including the rostrum, and are clothed with numerous hairs; the ischium and merus make about half the length of the endopod, and are strongly compressed and broad, the merus being considerably more than a third as broad as long; the carpus is about three-fifths as long and half as broad as the merus; the chela is somewhat stouter than the carpus, not far from twice as long, and tapered distally to the bases of the digits, which are about a third of the whole length, very slender and strongly curved at the tips. The fifth peræopods are about a fourth longer than the first and are clothed with very few hairs; the ischium and merus make fully half the entire length; both are broad and strongly compressed, and the latter is fully a third as broad as long, with the dorsal margin nearly straight and the ventral strongly curved upward to the articulation with the carpus, which is very slender and scarcely longer than the breadth of the merus; the propodus is about twice as long as the carpus and no stouter; the dactylus, exclusive of the terminal spines and 
setæ, is stout and about twice as long as the distal diameter of the propodus.

There is no carina on any somite of the pleon, but the dorsum of the third somite projects back in a small, vertically compressed spine over the fourth somite, in the dorsum of which there is an obscure, and possibly accidental, sulcus. The pleura are similar in outline to those of Acanthephyra Agassizii, but the second is relatively a little broader, the third and fourth more evenly rounded posteriorly, and the fifth a little more obtuse at the posterior angle. The sixth somite is about two-thirds as long as the carapax, excluding the rostrum, and less than half as high as long.

The telson is very much longer than the sixth somite, tapers into a very long and narrow tip, and is armed along the distal two-thirds of either edge with numerous (twenty to twenty-five) small aculei. The inner lamellæ of the uropods are about as long as the sixth somite of the pleon, lanceolate in outline, and less than a sixth as broad as long. The outer lamellæ reach to near the tip of the telson, are about six times as long as broad, and evenly rounded at the tips.

Measurements in millimetrers.

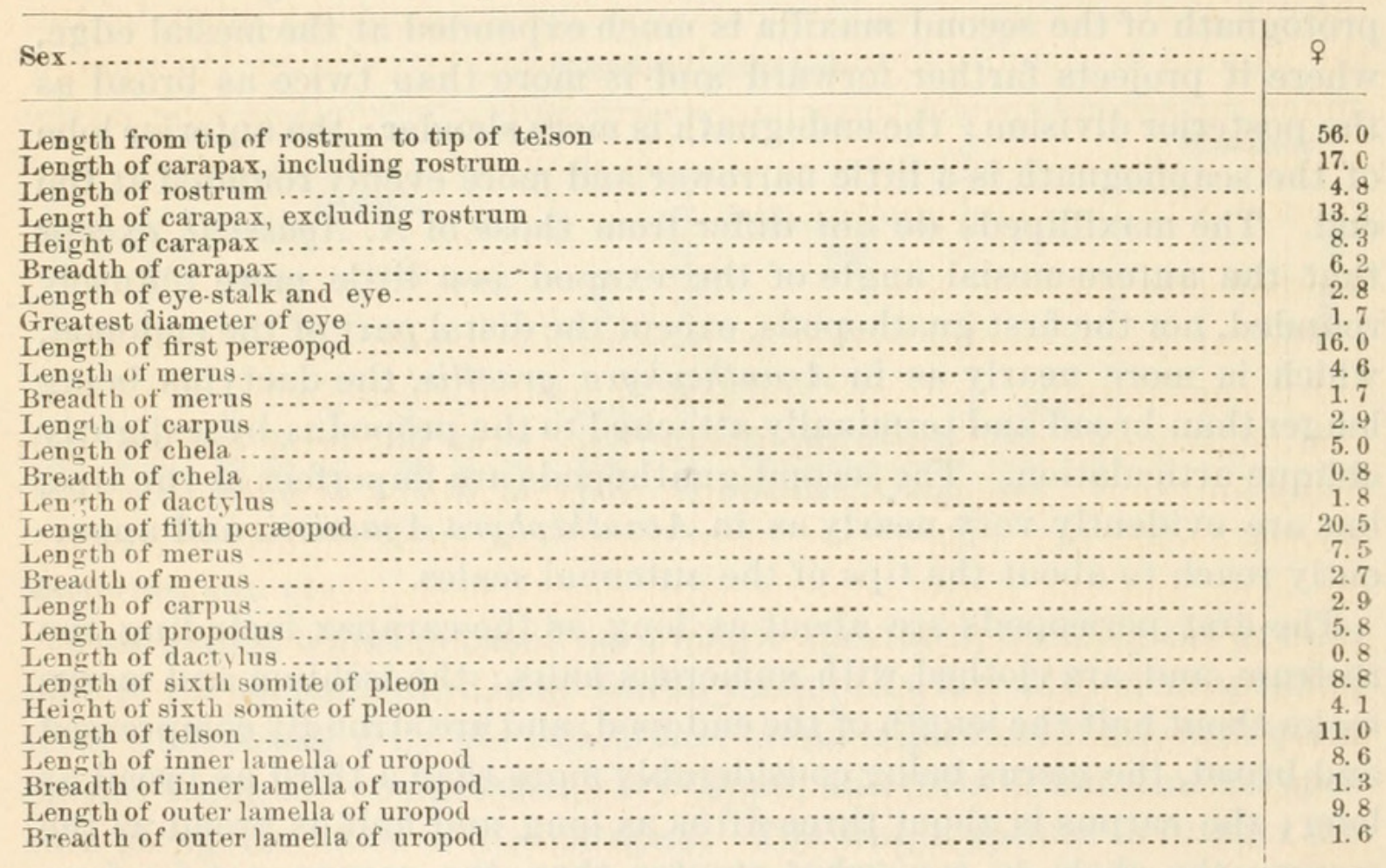

Station 2083, September 5, 1883, north latitude $40^{\circ} 26^{\prime} 40^{\prime \prime}$, west longitude $67^{\circ} 5^{\prime} 15^{\prime \prime}, 959$ fathoms, gray mud, temperature $40^{\circ}$, one female (7156).

Benthœcetes Bartletti Smith.

Benthesicymus? Bartletti Smith, Bull. Mus. Comp. Zool., x, p. 82, pl. 14, figs. 1-7, 1882.

Benthwcetes Bartletti Smith, Report U. S. Fish Com., x, for 1882, p. 391, pl. 10, fig. 8, 1884 .

Additional specimens of this species taken the present season show that the dactyli of the fourth and fifth peræopods are, as I had supposed, 
normally very slender, but not multiarticulate nor very long in either sex, and that the flagella of the antennula are very long, apparently much longer than the body.

\section{Benthonectes, gen. nov.}

This generic name is proposed for a species apparently very closely allied to that figured by A. Milne-Edwards as "Benthesicymus Bartletti (Smith)?" and probably specifically identical with it. The genus is closely allied to Benthocetes and is specially characterized by the multiarticulate flagelliform dactyli of the fourth and fifth peræopods. It is further distinguished from allied genera by the acute ventral process of the crowns of the mandibles and the narrow mandibular palpi; and probably, also, by the presence of an hepatic spine upon the carapax, the large reniform eyes, the equal lobes of the protognath of the second maxillæ, the absence or obsolesence of the third segment of the endopod of the maxilliped, the narrow merus of the first gnathopod, and the styliform dactylus of the second gnathopod. Like that of Benthocetes, the relation to Bates' imperfectly described Benthesicymus is largely prob. lematical, but Bates' genus is described as having the eyes "not large," the eye-stalks flattened and furnished with a conspicuous tubercle, and the flagella of the antennula "not longer than the carapax" (although under the second species these flagella are said to be "half as long as the animal"), characters which I should not expect to find in species congeneric with the one here described.

\section{Benthonectes filipes, sp. nov.}

The carapax is similar to that of Benthocetes Bartletti in general form, but is considerably narrower and less expanded posteriorly. The dorsum is carinated or slightly angulated to near the posterior border, and rising anteriorly projects forward in a rostrum almost exactly as in that species except that it is a very little longer, so as to slightly overreach the eyes, and the lower edge is more nearly horizontal. The inferior angle of the orbit is slightly more acute, the antennal spine a little larger and a little farther forward, and there is in addition an hepatic spine nearly as large as the antennal.

The eye-stalks are relatively short, and the very dark-brown eyes, large, swollen, reniform, project over the euds of the stalks and extend proximally along their mesial sides more than half way to the bases of the stalks, the greatest diameter of the eye being at least three-fourths of the whole length of the stalk. There is a small and inconspicuous tubercle on the mesial side of the stalk just back of the edge of the eye. The antennal scales are considerably narrower than in Benthocetes Burtletti, but otherwise the antennæ and antennulæ are essentially as in that species. The flagella of the anteunula are approximately equal in length, much longer than the body of the animal and very slender, while the flagellum of the antenna is very much longer and almost equally slender. 
The oral appendages are similar to those of Benthocetes Bartletti, but show some important differences. The ventral process of the crown of the mandible, instead of being truncated at the anterior angle, is prolonged into an acute angular process which closes by a similar process of the opposite side. The palpus is very different in form; the proximal segment is narrow, about three times as long as broad, reaches to about the tip of the crown, and expands very slightly distally; the distal segment is only about half as long as the proximal and about as wide at base, but the inner edge is obliquely truncated from just below the middle so that the obtuse tip is narrow. The first maxillæ differ only very slightly and unessentially. The endognath and epignath of the second maxillæ differ very little, but the four lobes of the protognath are very much more nearly alike, the distal lobe being only a very little broader than the others, while the proximal is very much like the others, being as long as the one next it and not narrowed toward the rounded tip. The endognath of the maxilliped is a little shorter and the small terminal segment either wanting or very obscure; the exopod is shorter and suddenly narrowed into a short and slender flagelliform tip. The exopod of the first gnathopod is very much smaller, being very slender and considerably shorter than the endopod. The endopod of the second gnathopod is more slender and armed with longer and stronger spines, and the dactylus is very different, being nearly two thirds as long as the propodus, slender, subcylindrical, and strongly tapered distally, where it is armed with several slender spines nearly as long as itself.

The chelate peræopods are similar to those of Benthoecetes Bartletti, but considerably longer and more slender, the first pair reaching considerably by the tips of the second gnathopods. The fourth and fifth peræopods are very long, exceedingly slender, and the proximal portions nearly as in Benthocetes Bartletti. The carpi in the fifth pair are considerably longer than the meri; the propodi in the fourth are much shorter than the carpi, and in the fifth not half as long as the carpi; the dactyli are slender, multiarticulate, flagelliform, and very long, being in the fourth pair fully three times as long as the propodi. The number and arrangement of the branchiæ and epipods are the same as in Benthocetes Bartletti, but there are small rudimentary exopods at the bases of all the peræopods, as in Benthesicymus ? carinatus.

The pleon is very similar to that of Benthoecetes Bartletti except that there is no spine on the fifth somite. The dorsum is evenly rounded on the first four somites, but on the fifth and sixth there is a sharp median carina which projects posteriorly in a very slight angle on each of these somites. The epimera are all somewhat smaller than in Benthocetes Bartletti, and the posterior edges of the fourth and fifth project much less and are broadly rounded. The sternum of the first somite is armed with a laterally compressed mesial process somewhat as in that species, but longer and obtuse. The pleopods have very long and slender rami, as in Benthocetes Bartletti, but the appendage (petasma) of the 
first pair in the male is very different, being as long as the protopod to which it is attached, very narrow, and acutely triangular at the tip.

Measurements in millimeters.

\begin{tabular}{|c|c|c|}
\hline Catalogue number .... & 8559 & 8020 \\
\hline Station......... & 2235 & 2181 \\
\hline Sex ... & $\delta$ & $\sigma^{\circ}$ \\
\hline Length from tip of rostruin to tip of telson & 82 & 63 \\
\hline Length of carapax including rostrum..... & 25. 7 & 32.0 \\
\hline $\begin{array}{l}\text { Length of rostrum } \ldots \ldots \ldots \ldots \ldots \ldots \\
\text { Height of carapax } \ldots \ldots \ldots \ldots \ldots\end{array}$ & $\begin{array}{r}6.0 \\
198\end{array}$ & 5.8 \\
\hline $\begin{array}{l}\text { Height of carapax } \ldots \ldots \ldots \ldots \ldots \ldots \ldots \ldots \ldots \\
\text { Breadth of carapax } \ldots \ldots \ldots \ldots \ldots \ldots \ldots \ldots\end{array}$ & $\begin{array}{l}12.8 \\
11.0\end{array}$ & $\begin{array}{l}9.6 \\
8.0\end{array}$ \\
\hline Length of eye-stalk and eye............... & 5. 0 & $\begin{array}{l}8.0 \\
4.1\end{array}$ \\
\hline Greatest diameter of eye............... & 3. 7 & 3.3 \\
\hline Length of antennal scale................. & 15.8 & 13. 5 \\
\hline $\begin{array}{l}\text { Breadth of antennal scale.................. } \\
\text { Length of second gnathopod ........... }\end{array}$ & 5.1 & 4. 0 \\
\hline & 24 & 20 \\
\hline 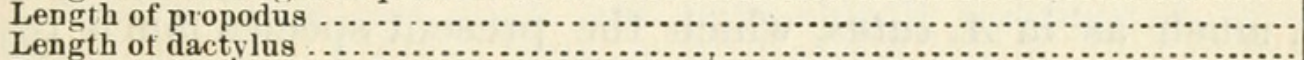 & 2.9 & 2.5 \\
\hline 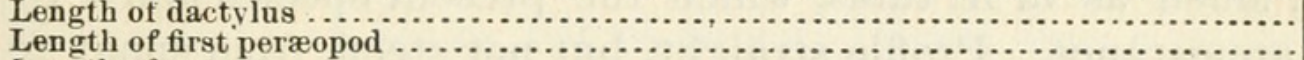 & 2. 0 & 1. 7 \\
\hline & 27 & 21 \\
\hline 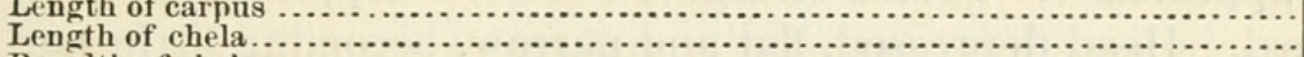 & $\begin{array}{l}6.0 \\
5.4\end{array}$ & 4.8 \\
\hline Breadth of chela ........................... & $\begin{array}{l}5.4 \\
1.0\end{array}$ & $\begin{array}{l}4.6 \\
0.9\end{array}$ \\
\hline Lengih of dactylus........................ & 2.5 & 2.1 \\
\hline 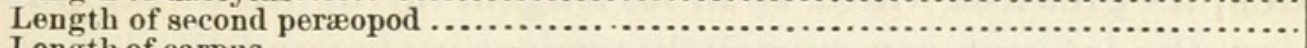 & 34 & 27 \\
\hline Length of earpus & 10. 0 & 8. 2 \\
\hline Length of chela........................ & 6. 0 & 5.0 \\
\hline $\begin{array}{l}\text { Breadth of chela } \ldots \ldots \ldots \ldots \ldots \ldots \ldots \ldots \ldots \ldots \ldots \ldots \ldots \ldots \ldots \ldots \ldots \\
\text { Length of dactvlus. }\end{array}$ & $\begin{array}{l}0.9 \\
2.8\end{array}$ & 0.7 \\
\hline 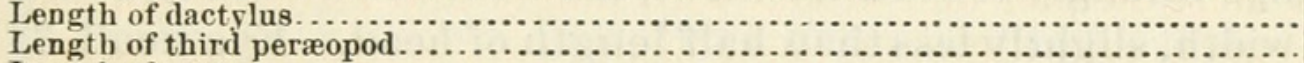 & 44.8 & 2.5 \\
\hline 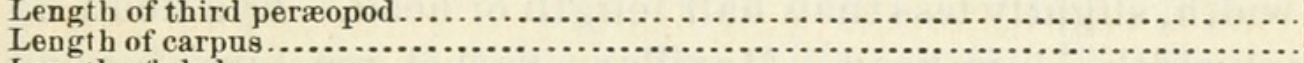 & $\begin{array}{l}44 \\
13.7\end{array}$ & 32 \\
\hline 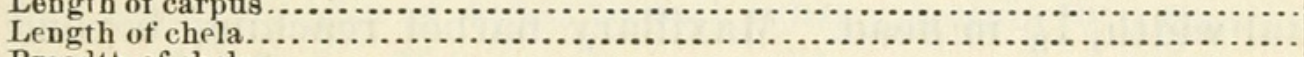 & 7. 4 & $\begin{array}{r}10.0 \\
5.5\end{array}$ \\
\hline (1) & 0.8 & $\begin{array}{l}5.5 \\
0.6\end{array}$ \\
\hline 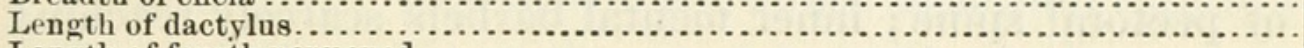 & 4.8 & 3.0 \\
\hline 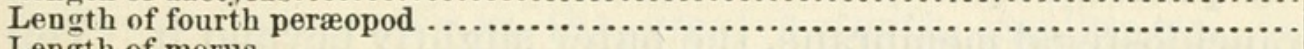 & 67 & 50 \\
\hline Length of merus & 13. 3 & 12. 0 \\
\hline 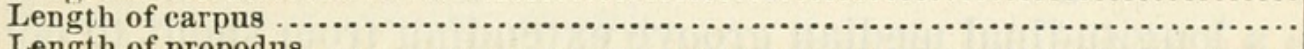 & 11. 0 & 8.4 \\
\hline Length of propodus. & 7.5 & 6. 0 \\
\hline 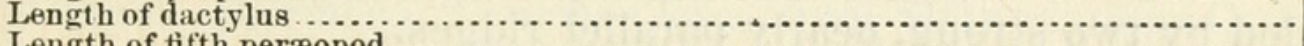 & 25.0 & 18.5 \\
\hline 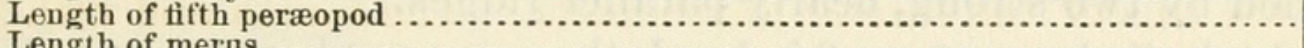 & $64+$ & …. \\
\hline 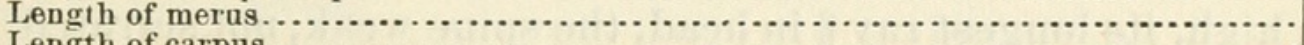 & 13. 0 & ..... \\
\hline $\begin{array}{l}\text { Length of carpus } \ldots \ldots \\
\text { Length of propodns }\end{array}$ & $\begin{array}{r}16.5 \\
7.7\end{array}$ & $\cdots$ \\
\hline 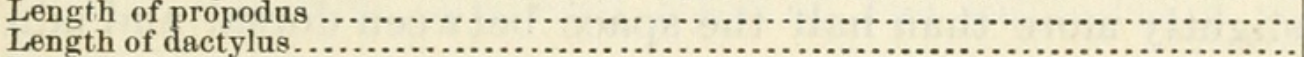 & $15+$ & \\
\hline 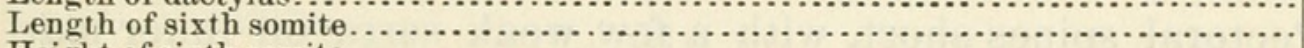 & 13.8 & ii. 0 \\
\hline 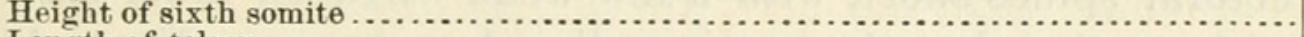 & 7.0 & 5.4 \\
\hline 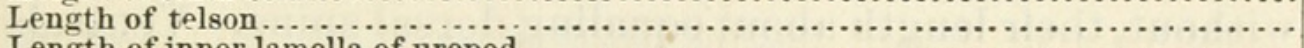 & 11. 0 & 9. 3 \\
\hline Length of inner lamella of uropod & 11. 5 & 9.2 \\
\hline Breadth of inner lamella of uropod.$\cdots \cdots$ & 2. 2 & 2. 3 \\
\hline 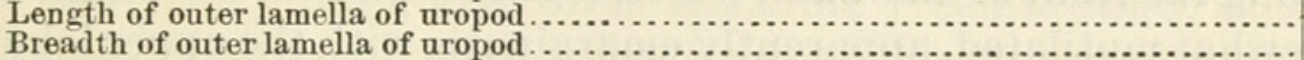 & 16. 4 & 14.8 \\
\hline & 4.5 & \\
\hline
\end{tabular}

Specimens examined.

\begin{tabular}{|c|c|c|c|c|c|c|c|c|c|c|c|c|c|}
\hline \multirow{2}{*}{ 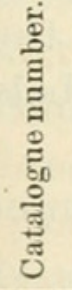 } & \multirow{2}{*}{ 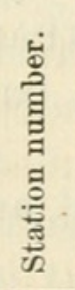 } & \multicolumn{6}{|c|}{ Locality. } & \multirow{2}{*}{$\frac{\text { Å }}{\text { Fath. }}$} & \multirow{2}{*}{ 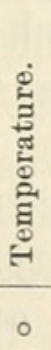 } & \multirow{2}{*}{ Nature of bottom. } & \multirow{2}{*}{ Date. } & \multirow{2}{*}{\multicolumn{2}{|c|}{$\frac{\dot{D}}{\stackrel{\Xi}{0}}$}} \\
\hline & & & T. la & & W. & lon & & & & & & & \\
\hline $\begin{array}{l}8020 \\
8265 \\
8266 \\
8559\end{array}$ & $\begin{array}{l}2181 \\
2206 \\
2210 \\
2235\end{array}$ & $\begin{array}{r}0 \\
39 \\
39 \\
39 \\
39\end{array}$ & $\begin{array}{l}1 \\
29 \\
35 \\
37 \\
12\end{array}$ & $\begin{array}{l}\prime \prime \\
00 \\
00 \\
45 \\
00\end{array}$ & $\begin{array}{r}\circ \\
71 \\
71 \\
71 \\
72\end{array}$ & $\begin{array}{l}1 \\
46 \\
24 \\
18 \\
03\end{array}$ & $\begin{array}{l}\prime \prime \\
00 \\
30 \\
45 \\
30\end{array}$ & $\begin{array}{r}\text { Fath. } \\
693 \\
1,043 \\
991 \\
707\end{array}$ & $\begin{array}{c}\circ \\
39 \\
38 \\
38 \\
39\end{array}$ & $\begin{array}{l}\text { Gray mud, fine sand } \ldots \ldots \ldots \ldots \\
\text { Green mud..................... } \\
\text { Gray globigerina ooze....... } \\
\text { Green mud } \ldots \ldots \ldots \ldots \ldots \ldots\end{array}$ & $\begin{array}{l}\text { 1884. } \\
\text { July } 23 \\
\text { Aug. } 20 \\
\text { Aug. } 21 \\
\text { Sept. } 13\end{array}$ & $\begin{array}{l}\text { o } \\
1 \mathrm{~s} . \\
1 \mathrm{~s} \\
1\end{array}$ & $\begin{array}{l}9 \\
\cdots 1 \\
\cdots \\
\cdots\end{array}$ \\
\hline
\end{tabular}

New Haven, Conn., October 30, 1884. 


\section{$2 \mathrm{BHL}$ Biodiversity Heritage Library}

Smith, S I. 1885. "On some new or little known Decapod Crustacea, from recent Fish Commission Dredgings off the East coast of the United States." Proceedings of the United States National Museum 7(455), 493-511. https://doi.org/10.5479/si.00963801.455.493.

View This Item Online: https://www.biodiversitylibrary.org/item/31798

DOI: https://doi.org/10.5479/si.00963801.455.493

Permalink: https://www.biodiversitylibrary.org/partpdf/11585

\section{Holding Institution}

Smithsonian Libraries

\section{Sponsored by}

Smithsonian

\section{Copyright \& Reuse}

Copyright Status: NOT_IN_COPYRIGHT

This document was created from content at the Biodiversity Heritage Library, the world's largest open access digital library for biodiversity literature and archives. Visit BHL at https://www.biodiversitylibrary.org. 